\title{
Utilization of Information Communication Technology and Associated factors among Academic Staffs in Bahirdar University, North West Ethiopia, 2019
}

\author{
Sisay Ebabye Tsigie \\ Department of Information Science \\ University of Gondar
}

\author{
Gizealew Alazie Dagnaw \\ Department of Information Science \\ University of Gondar
}

\begin{abstract}
Background: The realization of the benefits of ICT in the educational process to a large extent depends on the academic staffs that play crucial role in any innovation that takes place in the educational settings. The utilization of ICT in universities has been an issue that needs to be assessed in order to determine the extent to which ICT has utilized by the academic staff of the universities.
\end{abstract}

Objective: to assess utilization of Information Communication Technology (ICT) and associated factors in Bahirdar University academic staffs.

Methods: A quantitative cross-sectional study was conducted among 351 academic staffs that were selected using simple random sampling technique. It was conducted in all five campuses of Bahirdar University. The data was entered in to EPI INFO version 7.0 statistical software and then transferred to SPSS version 20.0 for further analysis.

Results and Discussion: 351 respondents, age from 24 to 60 years were participated in the study and included in the analysis. The constitute of male, ever marriage and urban residence of respondents were $82.3 \%, 74.4 \%$ and $39.9 \%$ respectively. $89.7 \%$ of study subjects had laptop computer. The extent of ICT utilization by academic staff reached $56.7 \%$. Of respondents with first degree education level only $4.8 \%$ of had good ICT utilization habit $[\mathrm{AOR}=0.048,95 \% \mathrm{CI}$ $(0.014,0.164)]$. This means individuals with first degree had 95.2\% less likely ICT utilization habit compared with their counter parts. Among poor ICT knowledge only $0.4 \%$ of had good ICT utilization habit [AOR=0.004, 95\% CI $(0.001$, $0.015)$ ]. Out of no training received individuals $2.8 \%$ of had good ICT utilization habit $[\mathrm{AOR}=0.028,95 \%$ CI $(0.006$, 0.132)].

Conclusion: ICT utilization habit of Academic staffs was found to be good. ICT knowledge, education level, laptop access, photocopier access, scanner access and ICT training were the prominent factor for ICT utilization among academic staffs.

\section{Keywords}

ICT, ICT Utilization, Academic Staffs, Bahirdar University

\section{INTRODUCTION}

Information Communication Technology (ICT) has become a powerful tool in the fight against world poverty, providing developing countries with an unprecedented opportunity to meet vital development goals, such as poverty reduction, basic health care, and education, far more effectively than before[1].With the swift advent of technology in previous decades, Information and Communication Technologies (ICT) have pervaded the workplace and fostered modern corporations along with providing governments with a proficient infrastructure[2].The ICT in Education Implementation Strategy and its corresponding Action Plan are components of a wider Ethiopian national e-education initiative. This initiative forms one of the pillars of the ICT for Development 2010 Plan[1]. One of the major application areas for ICT is education which is of vital importance in the knowledge society, as a source of basic skills, as a foundation for development of new knowledge and innovation, and as an engine for socio- economic development[3]. In the higher education institutions, the roles of academic staffs are geared towards achieving the University's national and international goals which include: Teaching learning, Research and Pursuit of services to the community and being a store house of knowledge. To accomplish these goals effectively and efficiently computer skill and its usage is becoming part of requirement[4]. Compared with developed countries, the use of ICT in education programs in developing nations is relatively limited. Some of the reasons mentioned for such gaps are because developing countries face shortages of financial resources, limited Internet access, a lack of trained teachers and the lack of proper policies[1].In today's competitive global information based economy, much pressure is on the university to produce graduates capable of running in the new world economic and societal environment brought by technological developments[5].The realization of the benefits of ICT in the educational process to a large extent depends on the academic staffs that play crucial role in any innovation that takes place in the educational settings[6]. The utilization of ICT in universities has been an issue that needs to be assessed in order to determine the extent to which ICT has utilized by the academic staff of the universities. But Bahirdar University is spending a huge amount of money on ICT related investments without knowing its utilization for the ICT's before. . The aim of this study therefore was to know the present utilization of ICT among academic staffs in Bahirdar University.

\section{METHOD}

An institution based quantitative cross-sectional study was conducted to assess utilization of Information and Communication Technology (ICT) and associated factors among academic staffs in Bahirdar University, North West Ethiopia 2017. The study was conducted in Bahirdar University which is found in Bahirdar city, North West Ethiopia. Bahirdar University was established by merging two former higher education institutions; namely the Bahir Dar Polytechnic and Bahirdar Teachers' College. The Bahirdar Polytechnic Institute, which has transformed itself into Technology and Textile institutes, was established in 1963 under the technical cooperation between the Government of USSR and the Imperial Government of Ethiopia. Bahirdar 
University has Five colleges, four institutes, two faculties and one school. The academic units of the University include College of Science, College of Agriculture and Environmental Sciences, College of Medical and Health Sciences, College of Business and Economics, College of Education and Behavioral Sciences, Bahirdar Institute of Technology, Ethiopia Institute of Textile and Fashion Technology, Institute of Land Administration, Institute of Disaster Risk Management and Food Security Studies, Faculty of Humanities, Faculty of Social Sciences, School of Law, Sport academy and Maritime academy..
The Data collection was conducted using structured and pretested self-administered questionnaire. The questionnaire was developed in English. The data was entered and edited manually in to EPI INFO version 7.0 statistical software and then transferred to SPSS version 20.0 for further analysis.

\section{RESULTS}

\subsection{Socio demographic characteristics}

In the table below is Socio-demographic characteristics of the respondents and the age classification was taken from the previous study in the same topic[7].

Table 1 Socio-demographic characteristics of Respondents in Bahirdar University, Bahirdar, Ethiopia, 2017(n=351).

\begin{tabular}{|c|c|c|c|}
\hline \multicolumn{2}{|c|}{ Variables } & \multirow{2}{*}{$\begin{array}{c}\text { Frequency } \\
53\end{array}$} & \multirow{2}{*}{$\begin{array}{c}\text { Percentage } \\
15.1\end{array}$} \\
\hline Age & $\leq 25$ & & \\
\hline & $26-29$ & 146 & 41.6 \\
\hline & $\geq 30$ & 152 & 43.3 \\
\hline \multirow[t]{2}{*}{ Sex } & Male & 289 & 82.3 \\
\hline & Female & 62 & 17.7 \\
\hline \multirow[t]{2}{*}{ Marital status } & Ever married & 261 & 74.4 \\
\hline & Never married & 90 & 25.6 \\
\hline \multirow[t]{4}{*}{ Religious } & Muslim & 45 & 12.8 \\
\hline & Orthodox Christian & 288 & 82.1 \\
\hline & Protestant & 12 & 3.4 \\
\hline & Others & 6 & 1.7 \\
\hline \multirow[t]{2}{*}{ Previous residence } & Rural & 211 & 60.1 \\
\hline & Urban & 140 & 39.1 \\
\hline \multirow[t]{10}{*}{ Field of study } & Agriculture & 19 & 5.4 \\
\hline & Education & 7 & 2.0 \\
\hline & Engineering & 48 & 13.7 \\
\hline & Health related science & 135 & 38.5 \\
\hline & Informatics & 12 & 3.4 \\
\hline & Law & 6 & 1.7 \\
\hline & Natural science & 33 & 9.4 \\
\hline & Business \& Economics related & 24 & 6.8 \\
\hline & Social science & 54 & 15.4 \\
\hline & Veterinary health & 13 & 3.7 \\
\hline Work experience & $<=5$ & 93 & 26.5 \\
\hline \multirow[t]{2}{*}{ (year) } & $6-10$ & 187 & 53.3 \\
\hline & $>=11$ & 71 & 20.2 \\
\hline \multirow[t]{2}{*}{ Level of Education } & MSc \& above & 266 & 75.8 \\
\hline & First Degree & 85 & 24.2 \\
\hline \multirow[t]{2}{*}{ Have Position } & Yes & 71 & 20.2 \\
\hline & No & 280 & 79.8 \\
\hline \multirow[t]{2}{*}{ Receive ICT training } & Yes & 105 & 29.9 \\
\hline & No & 246 & 70.1 \\
\hline
\end{tabular}


A total of 351 respondents, age from 24 to 60 years were participated in the study and included in the analysis $(100 \%$ response rate).Based on the demographic and other personal background information obtained, from the total respondents 289(82.3\%) were males. The highest number of respondents was in the age group of greater than or equal to thirty years $152(43.3 \%)$ and the smallest number was in the age less than or equal to 25 years $53(15.1 \%)$.

\subsection{ICT facilities Access and ICT knowledge}

Table 2 ICT facilities access and ICT knowledge of Respondents in Bahirdar University, Bahirdar, Ethiopia, 2017(n=351).

\begin{tabular}{|c|c|c|c|}
\hline \multicolumn{2}{|c|}{ Variables } & \multirow{2}{*}{$\begin{array}{c}\text { Frequency } \\
207\end{array}$} & \multirow{2}{*}{$\begin{array}{c}\text { Percentage } \\
59.0\end{array}$} \\
\hline Desktop & Yes & & \\
\hline & No & 144 & 41.0 \\
\hline \multirow[t]{2}{*}{ Laptop } & Yes & 315 & 89.7 \\
\hline & No & 36 & 10.3 \\
\hline \multirow[t]{2}{*}{ Laptop sources } & Private & 25 & 7.9 \\
\hline & University's Laptop & 290 & 92.1 \\
\hline \multirow[t]{2}{*}{ Office LAN } & Yes & 192 & 54.7 \\
\hline & No & 159 & 45.3 \\
\hline \multirow[t]{2}{*}{ Office WIFI } & Yes & 253 & 72.1 \\
\hline & No & 98 & 27.9 \\
\hline \multirow[t]{2}{*}{ printer } & Yes & 71 & 20.2 \\
\hline & No & 280 & 79.8 \\
\hline \multirow[t]{2}{*}{ Scanner } & Yes & 18 & 5.1 \\
\hline & No & 333 & 94.9 \\
\hline \multirow[t]{2}{*}{ Photo copier } & Yes & 26 & 7.4 \\
\hline & No & 325 & 92.6 \\
\hline \multirow[t]{2}{*}{ Projector } & Yes & 261 & 74.4 \\
\hline & No & 90 & 25.6 \\
\hline Class missed by & Yes & 69 & 76.7 \\
\hline lack of Projector & No & 21 & 23.3 \\
\hline \multirow[t]{2}{*}{ Home WIFI } & Yes & 289 & 82.3 \\
\hline & No & 62 & 17.7 \\
\hline Home WIFI & Private & 5 & 1.7 \\
\hline sources & University's WIFI & 284 & 98.3 \\
\hline \multirow[t]{2}{*}{ Smart board } & Yes & 22 & 6.3 \\
\hline & No & 329 & 93.7 \\
\hline \multirow[t]{2}{*}{ IP-Telephone } & Yes & 33 & 9.4 \\
\hline & No & 318 & 90.6 \\
\hline \multirow[t]{2}{*}{ Fax machine } & Yes & 7 & 2.0 \\
\hline & No & 344 & 98.0 \\
\hline \multirow[t]{2}{*}{ ICT knowledge } & Good & 234 & 66.7 \\
\hline & Poor & 117 & 33.3 \\
\hline
\end{tabular}

Regarding to education level majority of the respondents $266(75.8 \%)$ were MSC and above and most of the respondents 187(53.3)were with working experience of 6-10 years. The ever marriage and never marriage of the respondents were $261(74.4 \%)$ and $90(25.6 \%)$ respectively. 
As the table above showed owned and not owned desktop computers were $207(59.0 \%$ ) and $144(41.0 \%$ ) respectively and only $192(54.7 \%)$ of the total respondent have an access to LAN network in their Office and that of WIFI users were $253(72.1 \%)$. Two hundred sixthly one $(74.4 \%)$ of respondents had projectors in and near their office but this machine is inaccessible to $90(25.6 \%)$ of them. Among those who had not access to projector $69(76.7 \%)$ were missed the class. On the same way majority of the study participants $315(89.7 \%)$ were owned laptops and among those who had laptops, $25(7.9 \%)$ were owned their private laptops and 290(92.1.4\%) were university's Laptop. Regarding to ICT knowledge, 234(66.7\%) were had Good ICT knowledge and $117(33.3 \%)$ were had Poor ICT knowledge. From the finding the extent of ICT utilization by academic staff reached $56.7 \%$.

\subsection{Factors associated with ICT utilization}

Table 3: bivariate and multivariate analysis of ICT utilization and associated factors

\begin{tabular}{|c|c|c|c|c|c|}
\hline & & \multicolumn{2}{|c|}{ ICT utilization } & \multirow[b]{2}{*}{ COR $(\mathrm{CI}=95 \%)$} & \multirow[b]{2}{*}{$\operatorname{AOR}(\mathrm{CI}=95 \%)$} \\
\hline Variables & & Good & Poor & & \\
\hline \multirow[t]{2}{*}{ Position } & Yes & 52 & 19 & 1 & 1 \\
\hline & No & 147 & 133 & $0.404(0.227,0.718)$ & $0.454(0.104,1.990)$ \\
\hline \multirow[t]{2}{*}{$\begin{array}{c}\text { Education } \\
\text { level }\end{array}$} & $\begin{array}{c}2^{\text {nd }} \text { degree } \\
\text { \&above }\end{array}$ & 178 & 88 & 1 & 1 \\
\hline & $1^{\text {st }}$ degree & 21 & 64 & $0.162(0.093,0.283)$ & $0.048(0.014,0.161)^{*}$ \\
\hline \multirow{2}{*}{$\begin{array}{c}\text { ICT } \\
\text { knowledge }\end{array}$} & Good & 193 & 41 & 1 & 1 \\
\hline & Poor & 6 & 111 & $0.011(0.005,0.028)$ & $0.004(0.001,0.015) *$ \\
\hline \multirow{2}{*}{$\begin{array}{c}\text { Take } \\
\text { training }\end{array}$} & Yes & 97 & 8 & 1 & 1 \\
\hline & No & 102 & 144 & $0.058(0.027,0.125)$ & $0.028(0.006,0.132) *$ \\
\hline \multirow[t]{2}{*}{ generator } & Yes & 30 & 12 & 1 & 1 \\
\hline & No & 169 & 140 & $0.483(0.238,0.978)$ & $0.426(0.009,1.834)$ \\
\hline \multirow[t]{2}{*}{ Have laptop } & Yes & 196 & 119 & 1 & 1 \\
\hline & No & 3 & 33 & $0.055(0.017,0.184)$ & $0.035(0.004,0.279) *$ \\
\hline \multirow[t]{2}{*}{ LAN } & Yes & 116 & 76 & 1 & 1 \\
\hline & No & 83 & 76 & $0.716(0.468,1.094)$ & $1.328(0.498,3.539)$ \\
\hline \multirow[t]{2}{*}{ Printer } & Yes & 58 & 13 & 1 & 1 \\
\hline & No & 141 & 139 & $0.227(0.119,0.434)$ & $2.583(0.531,12.569)$ \\
\hline \multirow[t]{2}{*}{ photocopier } & Yes & 25 & 1 & 1 & 1 \\
\hline & No & 174 & 151 & $0.046(006,0.344)$ & $0.021(0.001,0.657) *$ \\
\hline \multirow[t]{2}{*}{ Scanner } & Yes & 17 & 1 & 1 & 1 \\
\hline & No & 182 & 151 & $0.071(0.009,0.539)$ & $0.002(0,0.498) *$ \\
\hline \multirow{2}{*}{$\begin{array}{c}\text { IP- } \\
\text { telephone }\end{array}$} & Yes & 32 & 1 & 1 & 1 \\
\hline & No & 167 & 150 & $0.035(0.005,0.258)$ & $0.052(0.001,2.025)$ \\
\hline \multirow{2}{*}{$\begin{array}{l}\text { Smart } \\
\text { board }\end{array}$} & Yes & 17 & 5 & 1 & 1 \\
\hline & No & 182 & 147 & $0.364(0.131,1.010)$ & $0.161(0.001,2.404)$ \\
\hline \multirow[t]{2}{*}{ Projector } & Yes & 63 & 27 & 1 & 1 \\
\hline & No & 136 & 125 & $0.466(0.279,0.778)$ & $0.280(0.071,1.108)$ \\
\hline
\end{tabular}

Based on the results of bivariate and multivariate analysis, the significant predictors of ICT utilization in Bahirdar university of academic staffs at 5\% significant level were; education level ,ICT knowledge, ICT training, laptop computer, photocopier and scanner. Of respondents with first degree education level only $4.8 \%$ of had good ICT utilization habit [AOR $=0.048,95 \%$ CI $(0.014,0.164)]$. This means individuals with first degree had $95.2 \%$ less likely good ICT utilization habit compared with their counter parts. Regarding with ICT knowledge, among poor ICT knowledge respondents only $0.4 \%$ of had good ICT utilization habit $[\mathrm{AOR}=0.004,95 \% \mathrm{CI}$ $(0.001,0.015)]$, which means they had $99.6 \%$ less likely good ICT utilization habit compared with their counter parts. Out of no training received individuals $2.8 \%$ of had good ICT utilization habit $[\mathrm{AOR}=0.028,95 \% \mathrm{CI}(0.006,0.132)]$.It is mean that no training received academic staffs had $97.2 \%$ less 
likely good ICT utilization habit compared with training received individuals.

\section{DISCUSSION}

The main purpose of this research was to investigate the Utilization of Information Communication Technology and associated factors among academic staffs in Bahirdar University, Northwest Ethiopia. This study revealed that the status of ICT utilization among academic staffs in Bahirdar Universitywas $56.7 \%$. This result was greater than the findings done in Christian university Uganda which reported as $45 \%$ of academic staffs had good ICT utilization habit[8]. This may be due to ICT facility access difference between the two institutions. For example laptop access in my study area is $89.7 \%$ where as in Christian university of Uganda is $83.2 \%$. This access difference is mainly because of that Bahirdar university sponsored laptops for academic staffs but not in Christian university of Uganda. On the other hand, ICT utilization habit of academic staffs in this study was less than the findings done in Nigeria which revealed that, over $65.0 \%$ of the academic staff utilized ICT effectively with $73 \%$ of ICT knowledge [9].The variation seemed due to ICT knowledge and training difference between the two institutions. For example ICT knowledge and ICT training of academic staffs in my study area and Nigerian study compared earlier was $66.7 \%, 29.9 \%$ and $73 \%, 82.35 \%$ respectively. This difference is accounted by the openness of the country for external support and institutional internationalization.

The study conducted in Malaysia with similar topic reported that, ICT utilization of lecturers was 68\% [10] which was greater than the result of this study. This difference was may be the socio economic difference between the two studies subjects. In this study most of academic staffs had laptop computers and this is attributed positively for good ICT utilization habit of the study subjects. On the other hand ICT training of academic staffs were very low and this variable was one of the factors that hider ICT utilization habit of the study subjects.

However computer and internet access were very good, the respondents ICT access in most ICT facilities were limited for example, photocopier and scanners were the scarcest and they were factors in determining ICT utilization.

\section{CONCLUSION}

The study determined utilization of Information communication technologies (ICT) among academic staffs. It as discovered that however, associated factors were existing; ICT utilization habit of Academic staffs in Bahirdar University was found to be good. Education level, ICT knowledge, ICT training, laptop computer access, photocopier access and scanner access were the prominent factor for ICT utilization among academic staffs in Bahirdar University. This was evident from the study that individuals with first degree, Poor ICT knowledge and no training receive were highly loosed to good ICT utilization .similarly laptop access, photocopier access and scanner access were affect ICT utilization habit. Insufficient training could be the reason for why percentage of ICT utilization is not in line with laptop access. So to enhance ICT utilization habit of academic staffs in the university the identified associated factors should be addressed and appropriate ICT knowledge should be integrated with ICT access.

\section{Abbreviations}

AOR: Adjusted Odd Ratio;CI: Confidence Interval; ICT: Information communication technology

\section{Competing interests}

The authors declare that they have no competing interests.

\section{ACKNOWLEDGEMENT}

We thank the academic staffs for participating in the study.

\section{REFERENCES}

[1] S. A. Woreta, Y. Kebede, and D. T. Zegeye, "Knowledge and utilization of information communication technology (ICT) among health science students at the University of Gondar, North Western Ethiopia," BMC medical informatics and decision making, vol. 13, p. 31, 2013.

[2] E. Kiraz and D. Ozdemir, "The relationship between educational ideologies and technology acceptance in preservice teachers," Educational Technology \& Society, vol. 9, pp. 152-165, 2006.

[3] B. M. Alemu, A. Makina, M. Madiope, O. A. Famade, J. O. Egbebi, F. O. Akinkuowo, et al., "Transforming educational practices of Ethiopia into development and the knowledge society through information and communication technology."

[4] F. Mikre, "The Roles of Information Communication Technologies in Education Review Article with Emphasis to the Computer and Internet," Ethiopian Journal of Education \& Science vol. Vol. 6 No 2, 2011.

[5] I. A. Archibong and D. O. Effiom, "ICT in University Education: Usage and Challenges among Academic Staff (Pp. 404-414)," African Research Review, vol. 3, pp. 404-414, 2009.

[6] I. A. Archibong, J. Ogbiji, and F. Anijaobi-Idem, "ICT competence among academic staff in universities in Cross Rivers State, Nigeria," Computer and Information Science, vol. 3, p. 109, 2010.

[7] ebrahim, "knowledge and utilization of computer among health workers in Addis Ababa hospitals" 2013.

[8] S. Kyakulumbye, M. Olobo, and V. Kisenyi, "Information Communication Technology (ICT) Utilization in Private Universities in Uganda: Exploring Strategies to Improve. A Case of Uganda Christian University," 2013.

[9] A. F. O. Yusuf Musibau Adeoye*, Loto Antonia Blessing, "Appraising the role of information communication technology (ICT) as a change agent for higher education in Nigeria," International Journal of Educational Administration and Policy Studies, 2013.

[10] K. E. Hoque, "ICT Utilization among School Teachers and Principals in Malaysia," International Journal of Academic Research in Progressive Education and Development, vol. Vol. 1, No. 4, October 2012, 